\title{
Cienie codzienności.
}

Poetyka opisu

w Lalce w świetle

notatek o kompozycji

Bolesława Prusa

\section{Marcin Jauksz}

\section{ORCID: 0000-0002-8337-3640}

Mówienie o opisach przestrzeni i zapełniających ją przedmiotach w literaturze późnego wieku XIX to, wydawałoby się, zamknięty już rozdział dla nauki o literaturze. A jednak poetyka opisu, która wraz z przeobrażeniem paradygmatu realistycznego w literaturze ${ }^{1}$, zmienia się również, odnajdując swe miejsce w sercu problematyki krystalizującego się literackiego modernizmu, zachęca, by na problem dziewiętnastowiecznej mimesis spoglądać wciąż z poczuciem, że nie wszystko jeszcze jest jasne. Lalka Bolesława Prusa, która zajmuje szczególne miejsce w jego

\footnotetext{
${ }^{1}$ Pam Morris w swojej książce o realizmie mówi o właściwej realizmowi „ponadracjonalnej koherencji, którą zdawała się podszyta struktura fabuły, perspektywa narracyjna oraz charakterystyka postaci”, która zostaje zanegowana przez pisarzy modernistycznych. Pam Morris, Realism (London: Routledge, 2003), 24. Jak pisze Michael Irvin w swojej klasycznej pozycji o obrazowaniu, dla pisarzy okresu wiktoriańskiego naturalne było „zobaczyć, a przynajmniej udawać, że widzą, historie, które komponowali”. Irvin, którego interesuje nie tyle staranie pisarza, co stopień przekonania do rozrysowanego w słowach obrazu po stronie czytelnika, widzi w opisie zaniedbany, a kluczowy dla problemu reprezentacji w dziewiętnastowiecznej powieści wątek: „Wielcy powieściopisarze wiktoriańscy zwyczajowo mieli poświęcić sporo czasu malowaniu scenerii, ponieważ, jak Dickens, mieli bujną wyobraźnię, albo, jak Eliot albo Gissing, wierzyli w formacyjną i ograniczającą rolę społecznego milieu i tym samym dostrzegali potencjalne znaczenie nawet w drobnych fizycznych elementach otoczenia". Michael Irvin, Picturing. Description and Illusion in the Nineteenth-Century Novel (London: George Allen, 1979), 3-5.
} 
dorobku ${ }^{2}$, jest tu w przestrzeni polskiej literatury dziełem symptomatycznym i, wszystko na to wskazuje, pierwszą szansą na wykorzystanie w praktyce spisywanych po wieloletniej przerwie od 1886 roku „notatek o kompozycji”. Próba przełożenia swoich przemyśleń o współczesności na reguły artystycznego zapisu miała w oczach Prusa optymalizować komunikacyjną wydajność, przybliżać też twórcę do maksymalnej kontroli wynikających z tekstu sensów, być kolejnym krokiem w realizacji wielkiego celu, by świat uczynić lepszym, doskonałym kiedyś może, budować społeczeństwo złożone z użytecznych jednostek, a jednostki te czynić bardziej szczęśliwymi. Ten program, który w zapiskach Prusa streszczany jest formułą $\pm S z \pm U t \pm D$ (oznaczającą możliwy przyrost lub zmniejszenie stopnia odpowiednio szczęścia, użyteczności i doskonałości), od samego początku połączony jest z zadaniem opisania świata, opisania zwykłego życia. Działanie to wyrasta z pewnej epoki i samo jest, jak pisał Erich Auerbach, „produktem i częścią składową pewnej atmosfery”. Za autorem fundamentalnego studium o mimesis można wskazać na balzakowskie korzenie Prusowskiej wrażliwości i wykorzystać przy tym stwierdzenie, jakoby:

nowość postawy twórczej i nowy rodzaj przedmiotów, które ujmuje się poważnie, tragicznie, problemowo - spowodowały też stopniowy rozwój zupełnie nowego rodzaju stylu poważnego lub, jeśli kto woli, wysokiego; żadna z ustalonych dotychczas tonacji stylowych, określających charakter ekspresji i ujęcia przedmiotu [...] nie dawała się po prostu przenieść na nowy typ tworzywa; toteż z początku przejawiała się niejaka niepewność w sposobie określania poważnej postawy pisarskiej ${ }^{3}$.

Jednym z kluczowych zagadnień dla Prusa jest „jak rozkładać, dopełniać i zmieniać wypadki życia codziennego, aby one dostarczały materiału dla wszelkich uczuć, myśli i pragnień, choćby najwznioślejszych, a z drugiej strony - najbrzydszych i komicznych"4. Rzecz jasna w powieści realistycznej odpowiedź na to pytanie musi być sprzężona z tłem zdarzeń, rutyna zaś ukazana w jak najbogatszym splocie z przestrzenią - rozpoznawalną i prawdopodobną. Poetyka opisu Prusa dodaje do tego jednak jeszcze jeden, bogaty, wymiar dookreśleń: „Opis - stwierdza pisarz - jest szeregiem definicji. Ostatnim słowem tych definicji jest $\pm S z \pm U t \pm D ”[N K ~ I I]$.

Lalka jako „poligon” dla teoretycznych założeń Prusa jest jednocześnie projektem psychologicznym, projektem, którego postępy można śledzić dzięki zachowanym notatkom. Wyrastając z ambicji Prusa, by zostać „poważnym pisarzem” i zerwać z wizerunkiem publicysty, kronikarza i humorysty, zapiski te są próbą znalezienia sposobów na ujęcie bieżących czasów

${ }^{2}$ W powieści, w której pisarz zawarł „cały swój ówczesny splot ideowy i dramat życia polskiego”, jak pisał Zygmunt Szweykowski, „wszystkie środki, którymi się Prus uprzednio posługiwał, wszystkie niemal odcienie dostarczane czytelnikowi znajdą tu swe miejsce w tak pełnym, syntetycznym, a jednocześnie tak oryginalnym zespole, jak w żadnym innym utworze tego pisarza”. Zob. Zygmunt Szweykowski, Twórczość Bolesława Prusa, wyd. II (Warszawa: PIW, 1972), 161, 193.

${ }^{3}$ Erich Auerbach, Mimesis. Rzeczywistość przedstawiona w literaturze Zachodu, tłum. Zbigniew Żabicki (Warszawa: Prószyński i S-ka, [2004]), 454, 462. W przypadku Prusa znaczenie miałyby tu „łatki” publicysty i humorysty, który mierzy się ze zbyt skomplikowanym zadaniem, porywając się na formę powieściową. Bardzo serio przez pisarza traktowane zagadnienia kompozycji wpisują go w poczet tych, którzy dla tej „powagi codzienności” próbowali ambitnie odnaleźć właściwy ton.

${ }^{4}$ Bolesław Prus, Notatki twórcze. Tom II: Notatki o kompozycji 1886-1889, oprac. Magdalena Kreft, Anna Martuszewska (Warszawa-Lublin: Towarzystwo Literackie im. Adama Mickiewicza - Episteme, 2016), 163. Wszędzie dalej odniesienia do tego wydania podane bezpośrednio za cytatem z oznaczeniem NK II i podaniem numeru strony, wyróżnienia w tych cytatach (rozstrzelony druk) pochodzą od Prusa. 
w powieściową formę. Prus, zrywając $z$ ważnym wątkiem powieściowej tradycji, równolegle do Henry'ego Jamesa ${ }^{5}$, poświęca narracyjną uwagę psychologicznym detalom związanymi z otoczeniem, w którym zachodzą. Świat opisany przez Prusa wyrasta z jego doświadczenia Warszawy - ale aranżuje jej przestrzenie na użytek poszczególnych postaci, z nich budując panoramę stanów raczej niż katalog niewzruszonych lokacji. Powiązanie postaci z przedmiotami, na które ta patrzy, zdaje się kluczowym zagadnieniem poruszanym w notatkach z połowy lat osiemdziesiątych, wpisanym w przekonanie o konieczności dynamizacji opisywanych przestrzeni i ukazywania zjawisk w ich złożoności. Prus porusza się tu w obrębie diagnoz psychologicznych znanych od lat i cenionych przez niego autorów - Johna Stuarta Milla, Herberta Spencera i Hipolita Taine'a - które to myśli powracają też w czytanym najpewniej przez autora Lalki na przełomie 1886 i 1887 roku podręczniku Clarka Murraya ${ }^{6}$. Zasady psychologii są analizą życia umysłowego człowieka, jego procesów poznawczych i emocjonalnych, powiązanych z ważnym przekonaniem o szczególnej mocy literatury, która nie zdoła co prawda:

z taką żywością jak malarstwo lub rzeźba reprodukować obrazu wzrokowego, odległego przedmiotu lub dawno minionego zdarzenia; nie może też tak żywo wzruszyć duszy, jak to czyni muzyka; lecz za to dziedzina jej nie posiada tych granic, jakie krępują poprzednie sztuki. Może ona przy pomocy tzw. „barwnych słów” (word painting) przedstawić niejako dla oka obraz rzeczy oddalonych w czasie i przestrzeni. Przy tym obrazy jej nie są związane z sytuacją chwili, lecz zmieniają się wolniej lub szybciej z całą żywością ruchu. [...] Naginając zaś dźwięki mowy do biegu wypadków historycznych, do rozwijającego się łańcucha dowodów lub do objaśnienia powszechnej prawdy, może sprzęgnąć rozum z uczuciem i poruszyć duszę do zamierzonego celu z taką pewnością, jakiej nieokreślone impulsy muzyki nigdy nie osiągną?

To poczucie sprawstwa sztuki, zapisane w książce, którą można uznać za wyraz stosunkowo popularnej świadomości dotyczącej mechanizmów ludzkiej psychiki, wskazuje na istotny wymiar funkcjonowania literatury w społeczeństwie, poświadczany w polskim piśmiennictwie choćby przez erupcję utworów tendencyjnych w pierwszych dekadach po upadku powstania styczniowego. Mimo poczucia wyczerpania i stopniowego oswajania się z kłopotliwością estetycznego kompromisu, jakim były dzieła nastawione przede wszystkim na efekt dydaktyczny, idea kontrolowania procesu recepcji dzieła literackiego nie zanika wraz z dojrzewaniem realizmu, kształtowaniem się technik naturalistycznych i - wreszcie - narodzinami wrażliwości modernistycznej.

\footnotetext{
5 „Uwewnętrznienie fabuły oraz uważne odnotowywanie opinii postaci o nich samych i innych z ich otoczenia zdominowało powieść psychologiczną późnego wieku XIX, zwłaszcza tę Henry'ego Jamesa, którego praca doprowadziła do kompletnego rozdziału między moralnym sceptycyzmem i komiczną tradycją, w której była zakorzeniona. Ten okres włączył moralną powagę w obręb myśli, które do tego czasu prowokowały jedynie śmiech lub skłaniały do ironii, tym samym kontynuując bardziej generalną tendencję w historii powieści. Dzięki tej transformacji szkoła empatii zostawiła dwudziestowiecznej powieści w spadku swoje bogate zrozumienie najdrobniejszych drgań ludzkiej psychiki”; Thomas Pavel, „The Novel in Search of Itself: A Historical Morphology”, w The Novel. Vol. 2: Forms and Themes, red. Franco Moretti (Princeton-Oxford: Princeton University Press, 2006), 24-25.

${ }^{6}$ Książka Murraya ukazała się na przełomie października i listopada, zezwolenie na druk otrzymawszy już w kwietniu 1886 roku. Prus wspomina o niej w Kronice z 14 listopada 1886 roku, co sugeruje, że w jej posiadanie mógł wejść wkrótce po wydaniu. Nie omawia jej jednak, co pozostawia w sferze spekulacji fakt rychłego zainteresowania się podręcznikiem do psychologii. Zob. Bolesław Prus, Kroniki, oprac. Zygmunt Szweykowski, t. 9 (Warszawa: PIW 1960), 260 i 528.

${ }^{7}$ Clark Murray, Zasady psychologii. Podręcznik, tłum. Henryk Wernic, Jan Władysław Dawid, wyd. II (Warszawa: Teodor Paprocki i S-ka, 1906), 211.
} 
Poświadcza to w swych notatkach, poczynanych w tym samym czasie co pomysł na Lalkę, Prus, pytając,

1. Jaki wpływ mam zamiar wywrzeć na wolę czytelnika?

2. Jak przedstawić rzecz, aby ją dokładnie zrozumiał <i widział>?

3. Jak przedstawić szczegóły, aby je widział, odczuwał i czuł? [NK II, 145].

Z tego samego czasu wywodzą się przekonania, że zjawiska należy opisywać w przynajmniej dwóch zdaniach, by pozwolić na "doznanie uczucia zmiany” [NK II, 189], że trzeba notować „skutki psychologiczne, albowiem one nadają opisowi barwę uczuciową" [NK II, 190] i zwracać uwagę na to, co kogoś „najbardziej obchodzi” [NK II, 190]. To ukazane jest najdobitniej w pierwszym opisie sklepu Wokulskiego zawartym w powieści:

Obejrzawszy się, czy ma krawat na szyi, a zegarek i portmonetkę w kieszeniach, pan Ignacy wydobywał ze stolika wielki klucz i trochę zgarbiony, uroczyście otwierał tylne drzwi sklepu obite żelazną blachą. Wchodzili tam obaj ze służącym, zapalali parę płomyków gazu i podczas gdy służący zamiatał podłogę, pan Ignacy odczytywał przez binokle ze swego notatnika rozkład zajęć na dzień dzisiejszy.

„Oddać w banku osiemset rubli, aha... Do Lublina wysłać trzy albumy, tuzin portmonetek... Właśnie!... Do Wiednia przekaz na tysiąc dwieście guldenów... Z kolei odebrać transport... Zmonitować rymarza za nieodesłanie walizek... Bagatela!... Napisać list do Stasia... Bagatela..."

Skończywszy czytać, zapalał jeszcze kilka płomieni i przy ich blasku robił przegląd towarów w gablotkach i szafach.

„Spinki, szpilki, portmonety... dobrze... Rękawiczki, wachlarze, krawaty... tak jest... Laski, parasole, sakwojaże... A tu - albumy, neseserki... Szafirowy wczoraj sprzedano, naturalnie!... Lichtarze, kałamarze, przyciski... Porcelana... Ciekawym, dlaczego ten wazon odwrócili?... Z pewnością... Nie, nie uszkodzony... Lalki z włosami, teatr, karuzel... Trzeba na jutro postawić w oknie karuzel, bo już fontanna spowszedniała. Bagatela!... Ósma dochodzi... Założyłbym się, że Klejn będzie pierwszy, a Mraczewski ostatni. Naturalnie... Poznał się z jakąś guwernantką i już jej kupił neseserkę na rachunek i z rabatem... Rozumie się... Byle nie zaczął kupować bez rabatu i bez rachunku...".

Tak mruczał i chodził po sklepie przygarbiony, z rękoma w kieszeniach, a za nim jego pudel. Pan od czasu do czasu zatrzymywał się i oglądał jakiś przedmiot, pies przysiadał na podłodze i skrobał tylną nogą gęste kudły, a rzędem ustawione w szafie lalki małe, średnie i duże, brunetki i blondynki, przypatrywały się im martwymi oczami ${ }^{8}$.

W powyższym fragmencie, nasyconym bladym mrokiem poranka, dopatrzeć się można celowego stopniowania wyobrażanego sobie przez czytelnika oświetlenia, poszerzania horyzontu

\footnotetext{
${ }^{8}$ Bolesław Prus, Lalka, oprac. Józef Bachórz, wyd. II, przejrzane (Wrocław: Ossolineum, 1998), BN I 262, t. I, 23-24. Wszędzie dalej cytaty z powieści za tym wydaniem z oznaczeniem L i podaniem numeru tomu i strony bezpośrednio za cytatem.
} 
patrzenia wraz z zapalaniem kolejnych lamp - najpierw gdy Rzecki z służącym wchodzą do pomieszczenia, następnie gdy stary subiekt zapala kolejne świece, robiąc przegląd w gablotkach i szafach. Wyliczane przedmioty zostają tą poranną inwenturą zsubiektywizowane, wpisane w najnowszą historię sklepu, skrzętnie odnotowywaną w głowie bohatera. Opis prowadzony jest z perspektywy postaci, ale nie tylko Rzecki patrzy. Niby w powieści grozy z półek przypatrują im się też „martwymi oczami” lalki, których przez wzgląd na intrygujący tytuł powieści zignorować w tym momencie nie sposób. To, że ich spojrzenie jest w tym fragmencie nieco niesamowite, nadaje blademu opisowi rutyny szczególny charakter, a do dynamiki między powieściowymi perspektywami i opisami „stanów rzeczy” włącza dodatkowo pierwiastek tego, co niepoznawalne. Jest on istotny w kontekście współcześnie prowadzonych prób nazwania granic pozytywistycznej formacji dokonywanych w kontekście ogłoszonego w tym czasie po polsku pierwszej części Systematu filozofii syntetycznej Herberta Spencera9 ${ }^{9}$ Każe też sobie uświadomić, że dynamikę krzyżujących się spojrzeń i ograniczonego „oświetlenia” znacząco dookreśla Prus już w początkowych partiach powieści, w której i lalki, i inne martwe przedmioty także mogą zyskać głos, gdy poświęcić im dość uwagi.

„Wiele jest oświetleń fizycznych” - pisze w lutym 1887 roku Prus i wymienia dla przykładu świecę, gwiazdy, elektryczność, błyskawicę czy Słońce. „Tak samo - kontynuuje - i oświetleń duchowych jest wiele klas, a każda z nich ma różny stopień wartości i wzniosłości" [NK II, 162]. Wymienia przy tym pisarz postaci, które takie szczególne oświetlenie rzeczy mogą zapewniać - wśród nich mędrca, bohatera, dziecię czy wyrobnika [NK II, 163]. Mogą też być nimi, zaznacza, przedmioty.

Świat powieściowy Prusa to całość kreująca, jak pisała Zofia Mitosek, „model stosunków międzyludzkich oraz międzyprzedmiotowych" ${ }^{10}$, ale też relacji między człowiekiem a przedmiotami zachodzącymi. Analizowany przez badaczkę motyw (tytułowej?) lalki to tylko jeden z wątków. Już zacytowane wyżej „rozmowy” Rzeckiego z przedmiotami „zaludniającymi" gabloty pod czujnym spojrzeniem martwych lalek spoczywających na regałach budują szczególną atmosferę trwania, atmosferę wyrastającą z bardzo skrupulatnego podejścia do kwestii opisu osób, przestrzeni, w których przebywają i przedmiotów, z którymi wchodzą w stycznośćc ${ }^{11}$.

To, jak Rzecki patrzy na sklep, jak Prus sklep ten, wykorzystując tę postać, opisuje, ma w świetle jego teoretyzowania o opisie znaczenie kapitalne. I choć, jeśli uwierzyć Ewie Paczo-

\footnotetext{
${ }^{9}$ Zob. Maciej Gloger, „Pozytywizm: między nowoczesnością a modernizmem”, Pamiętnik Literacki, z. 1 (2007): 11; Henryk Markiewicz, Młoda Polska a dziedzictwo pozytywizmu, w Dialogi z tradycją. Rozprawy i szkice historycznoliterackie, Kraków: Universitas, 2007, 159.

${ }^{10}$ Zofia Mitosek, „Lalka” - epizod czy nazwa?, w Mimesis. Zjawisko i problem (Warszawa: Wydawnictwo Naukowe PWN, 1997), 254.

${ }^{11}$ Jak pisała Katarzyna Kościewicz:,Starannie przeprowadzony i zmierzający do uchwycenia całości opis znany ze szkiców fizjologicznych zostaje zredukowany u Prusa do ulotnej obserwacji, uchwyconego momentu, twarzy przechodnia wyłowionej z tłumu, na której skupia się uwaga bohatera. Dopiero z tych fragmentów przepuszczonych przez filtr świadomości bohaterów budowana jest całość". Katarzyna Kościewicz, Doświadczenie nowoczesności $w$ „Lalce” $i$ „Emancypantkach” Bolesława Prusa, w Bolesław Prus. Pisarz, publicysta, myśliciel, red. Maria Woźniakiewicz-Dziadosz, Stanisław Fita (Lublin: Wydawnictwo UMCS, 2003), 48
} 
skiej, opisany chwilę przed cytowaną sceną pokój Rzeckiego nie nosi znamion intymności ${ }^{12}$, to sklep z całą pewnością jest jego drugim (a może właśnie pierwszym) domem. W nim relacja bohatera z przestrzenią, choć mocno osadzona w rutynie, łączy się ze stałą ekscytacją, codzienność nabiera znamion niekończącej się przygody. „Jak rozkładać, dopełniać i zmieniać - pyta Prus - wypadki życia codziennego. Aby one dostarczały materiału dla wszelkich uczuć, myśli i pragnień, choćby najwznioślejszych, a z drugiej strony - najbrzydszych i komicznych?" [NK II, 163]. Ówczesna psychologia nie dawała na to jasnej odpowiedzi. Jak pisał Murray: „utrzymywano, że źródłem śmieszności są rozmaite własności przedmiotów”, takie jak „niestosowność, trywialność, moralna nicość, z którą w parze idzie uczucie siły, albo przesadne o sobie wyobrażenie”, ale, zauważa tenże psycholog, uczucie zawsze „zależy od dwóch warunków: jednego podmiotowego, drugiego przedmiotowego. Dlatego też nie wiedząc, w jakim kierunku w danej chwili pozostaje umysł do danej własności przedmiotu, nie można z góry powiedzieć, jakie ona wywoła uczucie"13.

Prus ma tego świadomość, co widać, gdy choćby o wspomnieniach pisze, że ich zderzenie z rzeczywistością prowadzić może do „komizmu, zakłopotania, nawet przerażenia, a dalej zdziwienia, podziwu, uwielbienia" [NK II, 45].

Odpowiedzią, jakiej udzielił sobie pisarz na pytanie o to, jak pokazywać sprawy codzienne świata, są po części fragmenty poświęcone codzienności, zawarte w pierwszych partiach Lalki; ale one budowane są przy wykorzystaniu specjalnej struktury planów wykorzystywanych w opisie:

Pierwszy plan stanowią osoby i rzeczy, które ogarniamy nie tylko zmysłami zewnętrznymi, ale nawet znamy ich myśli, uczucia i wolę. Są to jakby ja.

Drugi plan tworzą osoby i rzeczy tylko dostrzegane zmysłami zewnętrznymi.

Trzeci plan zajmują osoby i rzeczy oceniane tylko wzrokiem i słuchem.

Czwarty plan osoby i rzeczy znane tylko z wieści, z opowiadań niezbyt dokładnych.

Piąty plan osoby, rzeczy i zjawiska, których się domyślamy, niejasno odgadujemy byt ich

[NK II, 53-54] $]^{14}$.

Podporządkowanie opisu perspektywie podmiotu wynika według Prusa z chęci uczynienia opisywanych zjawisk, przestrzeni, przedmiotów i ludzi jak najbliższymi tym postrzeganym zmysłowo w życiu. Ta relacyjność zadomowiona jest w psychologicznym mapowaniu świata przez podmiot, rekonstruowanym przez ważnych dla autora Lalki filozofów.

\footnotetext{
${ }^{12}$ Ewa Paczoska, „«Lalka» - balkony i wnętrza”, w „Lalka” $i$ inne. Studia w stulecie polskiej powieści realistycznej, red. Józef Bachórz, Michał Głowiński (Warszawa: IBL PAN, 1992), 98-99.

${ }^{13}$ Murray, Zasady psychologii, 344.

${ }^{14} \mathrm{~W}$ październiku Prus wróci do kwestii, tym razem plany opisując tak: „I. To, co jest mną, co widzę i odczuwam całą istotą. II. Co działa na mnie i na co ja działam. III. Co działa na mnie, lecz na co ja nie mam wpływu. IV. Co widzę tylko i słyszę, lecz już nie działa na mnie. V. Co znam z pogłosek i bardzo odległych wpływów pośrednich" [NK II, 75].
} 
Także podkreślenie relacji między przedmiotami, podążenie w powyższym opisie za zasadą kojarzenia i porównania związaną z tworzeniem wyobrażeń ${ }^{15}$ przekłada się na dokonywany przez Rzeckiego przegląd. Prus nie każe wymieniać narratorowi zasobów składu, to, co znajduje się w sklepie, kataloguje bohater; Rzecki „tak się przechadzający” realizuje zadanie aktywnego skupiania uwagi czytelnika. Na podobnej zasadzie jednak działają w pierwszych partiach powieści fragmenty poświęcone wizycie Izabeli w sklepie czy następującym po nich medytacjom Wokulskiego-flâneura.

Dynamika i subiektywizacja przypisywane przez Prusa „skutecznemu” opisowi wyrastają również z notatek psychologicznych Juliana Ochorowicza, który w wydanych w połowie lat siedemdziesiątych Wrażeniach, uwagach i spostrzeżeniach pisał m.in.: „nie ma świadomości bez zmiany wrażeń”, „doświadczenie nie polega na ilości odebranych wrażeń, lecz na sposobie ich ujmowania i zachowania”, „przyjemność zmysłowa jest [...] słabszą od umysłowej”16. „Obróbka", jakiej dokonuje umysł, ma tu kluczowe znaczenie, to ona stanowi fundament tożsamości, gdyż, jak głosi Ochorowicz: „«ja» ciągle odbiera materiał do swego istnienia pod postacią wrażeń wewnętrznych"17. To owa gra, która toczy się w podmiocie, ostatecznie konstytuuje psychiczną rzeczywistość, to za jej sprawą przestrzeń istnieje przede wszystkim, także dla bohaterów Prusa. Dla pisarza opis trzeba tworzyć tak, „by pojęcia oderwane symbolizować przedmiotami realnymi, które w duszy ludzkiej wywołują skutek zamierzony, tj. najlepiej streszczają własność nacechowaną pojęciem”, a także „panować nad wyborem przedmiotów w ten sposób, ażeby wybrany symbol budził wyraźną ideę, ale jeszcze określone uczucie" [NK II, 56]. Przykładem niech będą fragmenty ukazujące wyprawę Wokulskiego na wielkanocną kwestę.

Wszedł do kościoła i zaraz na wstępie znowu uderzył go nowy widok. Kilka żebraczek i żebraków błagało o jałmużnę, którą Bóg zwróci litościwym w życiu przyszłym. Jedni z pobożnych całowali nogi Chrystusa umęczonego przez państwo rzymskie, inni w progu upadłszy na kolana wznosili do góry ręce i oczy, jakby zapatrzeni w nadziemską wizję. Kościół pogrążony był w ciemności,

której nie mógł rozproszyć blask kilkunastu świec płonących w srebrnych kandelabrach. Tu i ówdzie na posadzce świątyni widać było niewyraźne cienie ludzi leżących krzyżem albo zgiętych ku ziemi, jakby kryli się ze swoją pobożnością pełną pokory. Patrząc na te ciała nieruchome można było myśleć, że na chwilę opuściły je dusze i uciekły do jakiegoś lepszego świata.

„Rozumiem teraz - pomyślał Wokulski - dlaczego odwiedzanie kościołów umacnia wiarę. Tu wszystko urządzone jest tak, że przypomina wieczność" [L I, 195].

W tym fragmencie Prus zaiste układa zjawiska tak, by z opisu „dało się ułożyć konkretną galeri[ę] przedmiotów, grup i zjawisk" [NK II, 56]; widzi to sam bohater, oceniający aranżację wnętrza i słabe oświetlenie, niepozwalające dosięgnąć wzrokiem granic świątyni. Prus ponownie "gra” światłem i podpowiada skojarzenia. Znieruchomiali ludzie przynależeć się zdają do tej przestrzeni, budują wspólnie z nią znaczenia, które czytelnikowi podsuwa Wokulski. Me-

\footnotetext{
${ }^{15}$ Zob. Murray, Zasady psychologii, 103.

${ }^{16}$ Julian Ochorowicz, Z dziennika psychologa. Wrażenia, uwagi i spostrzeżenia (Warszawa: Władysław Dębski 1876), 110, 179, 217.

${ }^{17}$ Ochorowicz, 102.
} 
chanizm takiego budowania znaczeń kontynuowany jest w dalszych partiach opisu świątyni, podporządkowanej perspektywie postaci:

Od pogrążonych w modlitwie cieniów wzrok jego pobiegł ku światłu. I zobaczył w różnych punktach świątyni stoły okryte dywanami, na nich tace pełne bankocetli, srebra i złota, a dokoła nich damy siedzące na wygodnych fotelach, odziane w jedwab, pióra i aksamity, otoczone wesołą młodzieżą. Najpobożniejsze pukały na przechodniów, wszystkie rozmawiały i bawiły się jak na raucie.

Zdawało się Wokulskiemu, że w tej chwili widzi przed sobą trzy światy. Jeden (dawno już zeszedł z ziemi), który modlił się i dźwigał na chwałę Boga potężne gmachy. Drugi, ubogi i pokorny, który umiał modlić się, lecz wznosił tylko lepianki, i - trzeci, który dla siebie murował pałace, ale już zapomniał o modlitwie i z domów bożych zrobił miejsce schadzek; jak niefrasobliwe ptaki, które budują gniazda i zawodzą pieśni na grobach poległych bohaterów.

„A czymże ja jestem, zarówno obcy im wszystkim?...” [L I, 197].

Elementy przestrzeni ponownie zostają podporządkowane perspektywie bohatera, którego uwaga pada na to, co rozświetlone, ale która też krytycznie do tego podchodzi. Szereg, czy jak napisałby Prus: „wiązka wrażeń w danej chwili”, prowadzi Wokulskiego do poczucia wyobcowania, tym samym nie zaspokaja jego potrzeb; prowadzić też może czytelnika ku „uczuciom złożonym i umysłowym” [NK II 60], przez Prusa sugerowanym na tle prowadzonej we fragmencie społecznej krytyki. Być może wszystko to da się podporządkować perspektywie psychologicznej, w czym pomogłyby słowa Murraya, łączące teoretyczne eksperymenty Prusa z tradycją myślenia o sztuce zaangażowanej:

Artysta, będąc działaczem moralnym, powinien mieć pewien moralny cel w swej czynności artystycznej, jak i w innych sferach swego postępowania. Przy tym, ponieważ dzieło sztuki jest wytworem gwoli przyjemności intelektualnej, przeto artysta nie powinien lekceważyć wartości moralnych uczuć, gdyż wszelkie rażące im ubliżenie zaszkodziłoby jego estetycznemu celowi. [...] Przyjemność estetyczna wynika z rozważenia sposobu, w jaki moralne objawy życia skombinowane zostały dla wywarcia estetycznego wrażenia ${ }^{18}$.

Gdy narrator Prusa, w ślad za jednym czy drugim bohaterem, faktycznie zatrzymuje wzrok na czymś, stara się zatrzymać ten obraz, spetryfikować go jakby konkretną myślą. To, co niewyrażalne, szuka w takich chwilach swojej ekspresji; zwyczajne przedmioty i zdarzenia oświetlone zostają z wielu stron i zaaranżowane odpowiednio dla uchwycenia praw życia. Prus również w tych powyższych fragmentach „podporządkowuje się” teorii opisu, który to, jak głosi jedna z pierwszych notatek temu zagadnieniu kompozycji poświęcona, „powinien być pełny, bryłowaty. Trzeba opisywać formę i materiał, powierzchowność i budowę wewnętrzną, nie tylko front przedmiotu, ale tył i boki" [NK II, 56]. Niezmienna jednak wydaje się przy tym zapisana nieco wcześniej uwaga, jakoby „uczucie winno być tłem każdego opisu przedmiotów”, kładąca podwaliny pod nastroje obecne w pisarstwie Prusa, nastroje zabarwiane przez nastawienie jego bohaterów: „poza przedmiotami opisywanymi może być parę uczuć zlanych w jedno jak 
barwy lub stojących obok siebie jak tony”, a „przedmioty z owymi uczuciami mogą być w harmonii lub dysharmonii" [NK II, 44].

W realizmie, jak pisze Morris, „epistemologiczny proces, w którym uczestniczy czytelnik powieści, naśladuje sposób, w jaki zdobywamy empiryczną wiedzę o aktualnym świecie społecznym i fizycznym za pośrednictwem obserwacji rzeczywistych detali, zachowań oraz wydarzeń"19. Badaczka wskazuje zasadę, na której Lalka opiera się bardziej niż jakakolwiek inna powieść ówczesna, odkrywając przed czytelnikiem każdego z bohaterów stopniowo, z początku ograniczając jego wiedzę i dopiero z czasem wynagradzając to opisem $\mathrm{z}$ wielu perspektyw i stron, dając wyobrażenie nie tylko odnośnie do frontu, ale też „tyłu i boków”. Do tego, dodać można za Michałem Głowińskim, Prus antycypuje znaczenia sceny powieściowej, rozluźniającej swój związek z ciągiem przyczynowo-skutkowym narracji ${ }^{20}$, każąc czytelnikowi rozglądać się raczej po sytuacji, niż zaprzęgać ją przede wszystkim w szereg wynikających z siebie zdarzeń. W scenie kwesty znaczenie dla większości czytelników będzie miało spotkanie z Izabelą, jednak poprzedzający je opis kościoła i przypisanych do obrazów wrażeń i uczuć postaci, określają istotę pęknięcia między bohaterem a wybranką jego serca, zmęczoną i znudzoną swoimi zadaniami i trudami losu. Tak dla czytelnika, jak i dla Wokulskiego wiążąca wydaje się myśl, jakoby „wszystkie te ceremonie” dawały „czas i możność zaznajomienia się” [L I, 203].

Lalka, modernizując sposób wprowadzania czytelnika w świat przedstawiony i budując napięcie związane z oczekiwaniem, wykorzystuje odnotowane przez współczesną Prusowi psychologię zasadę ciekawości ${ }^{21}$. Prus ambitnie podąża od szczegółów do uogólnień, starając się często realizować w praktyce swoją zasadę tłumaczenia zjawisk, zanotowaną w listopadzie 1886 roku:

Aby zjawisko było dobrze pojęte i odczute, musi być przedstawione tak, aby oddziaływało na wszelkie nasze uzdolnienia.

To osiągnąć można przez porównanie. Bo gdy np. jakieś zjawisko działa tylko na nasze zmysły, wówczas porównawszy go z biologicznym, poruszamy naszą myśl i uczucia. I na odwrót: gdy mamy zjawisko psychiczne, dobrze jest porównać je z fizycznym, aby poruszyło zmysły.

Opis jest zupełny i zadawalający, gdy poruszy wszystkie uzdolnienia ludzkie.

Również dla poruszenia wszystkich uzdolnień rozkładamy zjawisko na tyle podrzędnych v. składowych, ile jest uzdolnień ludzkich [NK II, 125].

\footnotetext{
${ }^{19}$ Morris, Realism, 11.

${ }^{20}$ Zob. Michał Głowiński, Powieść młodopolska. Studium z poetyki historycznej (Kraków: Universitas, 1997), 188189.

${ }^{21} \mathrm{O}$ ważnej dla epoki relacji między koncepcjami tożsamości a kwestią uwagi pisał w kontekście sztuki Jonathan Cary, stający na stanowisku, że „uwaga i rozproszenie muszą być ujmowane jako continuum, bezustanny przepływ jednego stanu w drugi, część pola społecznego, w którym oba pobudzane są przez te same nakazy i siły". Jonathan Cary, Zawieszenia percepcji. Uwaga, spektakl i kultura nowoczesna, tłum. Łukasz Zaremba, Iwona Kurz, red. Iwona Kurz (Warszawa: WUW, 2009), 73-74.
} 
Lista uzdolnień nie jest krótka, ale to ona otwiera bruliony notatek o kompozycji w 1886 roku i tym samym można ją brać za faktyczny punkt odniesienia dla zmierzających ku zupełności opisów. Nie byłoby produktywnym, wydaje się, sprawdzać (odhaczając), czy opis apartamentów Łęckich, jeden $\mathrm{z}$ bardziej tradycyjnych w powieści, realizuje ten ambitny cel uderzenia we wszystkie „klawisze” (jak je nazywa Prus) [NK II, 15]. Na pewno jednak przynosi ze sobą realizację założenia dotyczącego pokazywania przedmiotów w oczach patrzących nań osób, badania przestrzeni poprzez rozważanie możliwych reakcji, jakie ona wywołuje:

Mieszkanie posiadało wielkie zalety. Było suche, ciepłe, obszerne, widne. Miało marmurowe schody, gaz, dzwonki elektryczne i wodociągi. Każdy pokój w miarę potrzeby łączył się z innymi lub tworzył zamkniętą w sobie całość. Sprzętów wreszcie miało liczbę dostateczną, ani za mało, ani za wiele, a każdy odznaczał się raczej wygodną prostotą aniżeli skaczącymi do oczu ozdobami.

Kredens budził w widzu uczucie pewności, że z niego nie zginą srebra; łóżko przywodziło na myśl bezpieczny spoczynek dobrze zasłużonych; stół można było obciążyć, na krześle usiąść bez obawy załamania się, na fotelu marzyć.

Kto tu wszedł, miał swobodę ruchu; nie potrzebował lękać się, że mu coś zastąpi drogę lub że on coś zepsuje. Czekając na gospodarza nie nudził się, otaczały go bowiem rzeczy, które warto było oglądać. Zarazem widok przedmiotów, wyrobionych nie wczoraj i mogących służyć kilku pokoleniom, nastrajał go na jakiś ton uroczysty.

Na tym poważnym tle dobrze zarysowywali się jego mieszkańcy [L. I, 86; wyróżnienia moje - M.J.].

Następująca opowieść o Łęckich, ciekawa i bogata w detale, pozostaje w niezmąconej relacji z zajmowanymi przez nich przestrzeniami. Niedookreślenia w opisie, na jakie pozwala sobie Prus, będą mogli dopełnić swoimi cechami sami bohaterowie. Technika charakterystyki postaci poprzez jej milieu to charakterystyczna dla prozy wieku XIX operacja, wiążąca nierozerwalnie bohatera z przestrzenią, pozwalająca wnioskować o psychice na podstawie materialnych, twardych dowodów. Podobnie smutna izdebka Rzeckiego, pokazana przez Prusa, zanim czytelnik ruszy za subiektem do sklepu, ma sygnalizować „duchowy” wiek bohatera, przynależność do melancholijnego pokolenia, ale też stabilność jego charakteru; sam opis pokoju, enumeracja znajdujących się w nim przedmiotów (krótko scharakteryzowanych, zestawionych $z$ innymi) pozwala na skojarzenia związane $z$ konkretnymi elementami wystroju (spłowiałe firanki), sposobem ich używania, dbania o nie (poplamiony obrus) i tym, czy w ogóle są używane (świece i przeznaczone do przycinania ich knotów szczypce).

Podobnie jak introspekcja Izabeli w rozdziale VI powieści, wgląd w przeszłość Starego Subiekta ma za zadanie ukazać przestrzenie powieściowe w ujęciu nie tylko synchronicznym, ale i diachronicznym. Pokazany po raz pierwszy pod nieobecność pryncypała sklep Wokulskiego w spisywanym przez bohatera pamiętniku zyskuje inny charakter, tym razem "oświetlony” perspektywą dziecka. Przestrzeń ta, ogrzana ciepłem wspomnień Rzeckiego, malowana jest zgodnie ze wspomnianą już zasadą z notatek głoszącą, że „uczucie winno być tłem każdego opisu przedmiotów" [NK II, 44]. W oczach młodzieńca skład towarów stanie się niemalże grotą rozbójników, przestrzenią niezwykłych uniesień porównywalnych do tych, jakich doświadczają bohaterowie Baśni 1001 nocy: 
Sklep Mincla znałem od dawna, ponieważ ojciec wysyłał mnie do niego po papier, a ciotka po mydło. Zawsze biegłem tam z radosną ciekawością, ażeby napatrzeć się wiszącym za szybami zabawkom. O ile pamiętam, był tam w oknie duży kozak, który sam przez się skakał i machał rękoma, a we drzwiach - bęben, pałasz i skórzany koń z prawdziwym ogonem.

Wnętrze sklepu wyglądało jak duża piwnica, której końca nigdy nie mogłem dojrzeć z powodu ciemności. Wiem tylko, że po pieprz, kawę i liście bobkowe szło się na lewo do stołu, za którym stały ogromne szafy od sklepienia do podłogi napełnione szufladami. Papier zaś, atrament, talerze i szklanki sprzedawano przy stole na prawo, gdzie były szafy z szybami, a po mydło i krochmal szło się w głąb sklepu, gdzie było widać beczki i stosy pak drewnianych.

Nawet sklepienie było zajęte. Wisiały tam długie szeregi pęcherzy naładowanych gorczycą i farbami, ogromna lampa z daszkiem, która w zimie paliła się cały dzień, sieć pełna korków do butelek, wreszcie - wypchany krokodylek, długi może na półtora łokcia [L I 55-56].

Wspomnienie Rzeckiego może być dla czytelnika lekcją sentymentu. „Radosna ciekawość”, o której mówi bohater, wprowadza w przestrzeń zatłoczoną, której baśniowy charakter ewokuje przywołana dziecięca wrażliwość i niemożliwe do nasycenia łakomstwo wrażeń. Wszystkie wyliczone przedmioty wzbudzają sympatię, emocje dodatnie... Nastrój wspominającego Rzeckiego, po trochu melancholika, po trochu tetryka, zostaje tu zabarwiony entuzjazmem, którym nasycone jest wspomnienie.

Sklep budowany z subiektywnych wrażeń Rzeckiego kształtuje się również w myśl kompozycyjnej reguły „różniczkowania” Prusa - a więc pokazywanie elementów składowych przedmiotu czy zjawiska - i łączenia ich z konkretną perspektywą; w tym przypadku - perspektywą dziecka. Nieco inaczej „rozbiera” (na czynniki pierwsze) Prus córkę Łęckiego, wykorzystując ten opis raz jeszcze do pokazania, że konkretne znaczenie tego, na co patrzymy, warunkuje kontekst:

Panna Izabela była niepospolicie piękną kobietą. Wszystko w niej było oryginalne i doskonałe. Wzrost więcej niż średni, bardzo kształtna figura, bujne włosy blond z odcieniem popielatym, nosek prosty, usta trochę odchylone, zęby perłowe, ręce i stopy modelowe. Szczególne wrażenie robiły jej oczy, niekiedy ciemne i rozmarzone, niekiedy pełne iskier wesołości, czasem jasnoniebieskie i zimne jak lód.

Uderzająca była gra jej fizjognomii. Kiedy mówiła, mówiły jej usta, brwi, nozdrza, ręce, cała postawa, a nade wszystko oczy, którymi zdawało się, że chce przelać swoją duszę w słuchacza. Kiedy słuchała, zdawało się, że chce wypić duszę z opowiadającego. Jej oczy umiały tulić, pieścić, płakać bez łez, palić i mrozić. Niekiedy można było myśleć, że rozmarzona otoczy kogoś rękami i oprze mu głowę na ramieniu; lecz gdy szczęśliwy topniał z rozkoszy, nagle wykonywała jakiś ruch, który mówił, że schwycić jej niepodobna, gdyż albo wymknie się, albo odepchnie, albo po prostu każe lokajowi wyprowadzić wielbiciela za drzwi... [L I, 90].

Dynamika obu tych opisów - sklepu w dawnych czasach i Izabeli - skupia się na wrażeniach patrzących podmiotów. Jednym jest Rzecki wspominający swoje dawne „ja”; drugim domnie- 
many adorator Izabeli, której proteuszowy charakter utrudnia rozeznanie się w sytuacji i jego relacji z młodą kobietą. Prus, zgodnie z deklaracjami z notatek, nazywa najpierw całe „zjawisko" - czy to sklep, czy piękna i oryginalna kobieta; szybko jednak przechodzi do nazywania składowych i budowania napięć w obrębie prezentowanego bytu. Nieuchwytność Izabeli może się tu stać regułą robiącej uniki rzeczywistości, zagubienie zaś jej absztyfikanta - pozycją, jaką zajmuje wobec zjawisk duchowych badający je psycholog. Sytuacja bowiem nie jest tak prosta i tego świadomość Prus także nabywa. Być może za Murrayem uczy się rozumieć, że

nie możemy [...] powiedzieć, żeby wiedza rozpoczynała się od tego, co by można w ścisłym znaczeniu uważać za ogólne, ani też od tego, co w ścisłym znaczeniu uchodzić by mogło za pojedyncze. Ponieważ więc nie możemy zgodzić się ani na jedną teorię, ani na drugą, przeto do jednego tylko możemy dojść wniosku, mianowicie że wiedza musi się rozpoczynać od czegoś nieokreślonego. Przekonaliśmy się już [...], że surowym materiałem wiedzy, jak i wszelkiego życia umysłowego, są wrażenia. Prawda, że wrażeń nie można jeszcze nazwać poznaniem; lecz poznanie rozpoczyna się z ukazaniem wrażeń w świadomości, mianowicie z utożsamieniem tych, które są do siebie podobne i odróżnieniem tych, które się od siebie różnią. Ilekroć jestem świadomy, choćby ogólnikowo, że wrażenie, którego teraz doznaję, różni się od innych wrażeń, a podobne jest do pewnych innych wrażeń, jakich poprzednio doznałem, to wrażenie staje się w pewnym stopniu określonym, to jest wyraźnie poznanym².

Rdzeń tego wywodu nie mógł nie być Prusowi-tainiście obcy. Wszak to Hipolit Taine w ważnym studium $O$ inteligencji (obecnym w księgozbiorze pisarza ${ }^{23}$, a wydanym po polsku już w 1873 roku) pisał, że „można, z braku lepszej nazwy, powiedzieć za Condillakiem, że pierwszorzędnym wewnętrznym zjawiskiem stanowiącym nasze poznanie jest wrażenie" ${ }^{24}$. Tym samym wskazanie na to, co nieokreślone w procesie poznawczym mogło trafić na podatny grunt, zwłaszcza w świetle ważnego zapisku o teorii kompozycji z lutego 1887 roku:

a.Kompozycja rozwiązuje dwa rodzaje zagadnień:

B. Temat ogólny rozkłada na szereg zdań konkretnych, tworzących organiczną całość.

C. <Jakiś> Do faktu wyrażonego zdaniem konkretnym dorabia inne fakta, które z pierwszym tworzą całość organiczną.

Pierwszy rodzaj uprawiają mówcy, moraliści itp. Drugi - kronikarze. Powieściopisarz łączy oba.

Zdania ogólne można nazwać prawami ogólnymi, zdania konkretne - faktami. Otóż zarówno fakt $(f)$, jak i Prawo $(P)$ są dopiero jedną stroną równania. Drugą stroną równania jest jakaś władza, jakaś część duszy czytelnika, w której należy wywołać pewną grę uczuć, myśli i pragnień [NK II, 166-167].

\footnotetext{
${ }^{22}$ Murray, Zasady psychologii, 206.

${ }^{23}$ Zob. Halina Ilmurzyńska, Agnieszka Stepnowska, Księgozbiór Bolesława Prusa, red. Zygmunt Szweykowski (Warszawa: Stowarzyszenie Bibliotekarzy Polskich, 1965), 142.

${ }^{24}$ Hipolit Taine, O inteligencji, tłum. Stanisław? Tomaszewski (Warszawa: Skład Główny Redakcji „Niwy”, 1873), 292.
} 
Jak pisał Tomasz Sobieraj, „horyzonty poznawcze Prusowego arcydzieła zakreśla tedy przenikliwy dyskurs ideowy z wieloma problemami i wartościami konstytuującymi świadomość formacji kulturowej XIX wieku"25. Ich mnogość podnosi atrakcyjność rekonstruowania tej wrażliwości, ale też, podobnie jak od powieściopisarza tamtych czasów wymaga skupienia na efektach, na których ona się skupiała. Władza, o której pisze Prus, stanowiąca rewers monety, gdzie na awersie fakty wynikają lub potwierdzają pewne prawa, stanowi konieczny punkt, który musi być uwzględniony w dookreślaniu Prusowskiego horyzontu poznawczego. Podobnie Murrayowska koncepcja wrażenia „w pewien sposób określonego, wyraźnie poznanego” oraz stwierdzenie Taine’a jakoby „wszelki postęp wiedzy polegał na coraz bardziej określonym odróżnianiu zjawiska od zjawisk różnych od niego i na jego utożsamianiu z tymi, do których jest podobne"26, stanowią punkty odniesienia do Prusowskiego usytuowania powieściopisarstwa jako działania artystycznego, oddanego zadaniu reprezentacji, ale też przede wszystkim budowaniu szczególnego obrazu, sytuacji dla wywołania konkretnego uczucia, dalej efektu poznawczego i konkretnego działania (wpływu na wolę) [NK II, 151], na przekór wątpliwościom. Wszystko to odbywa się niezmiennie po linii realistycznych konwencji; w nowatorstwie Lalki znać jednak ślad Prusowskich analiz ducha w praktyce opisu, analiz, które z jednej strony miały pozwolić na odczucie i zrozumienie świata bohaterów w najpełniejszy możliwy sposób, z drugiej zaś poświadczały tego świata nieuchwytność.

\footnotetext{
${ }^{25}$ Tomasz Sobieraj, „«Lalka» na horyzoncie dziewiętnastowieczności (modernizmu), w Świat „Lalki”. 15 studiów, red. Jakub A. Malik (Lublin: Towarzystwo Naukowe KUL, 2005), 10-11.

${ }^{26}$ Murray, Zasady psychologii, 206.
} 


\section{Bibliografia}

Auerbach, Erich. Mimesis. Rzeczywistość przedstawiona $w$ literaturze Zachodu. Przetłumaczone przez Zbigniew Żabicki. Warszawa: Prószyński i S-ka [2004].

Cary, Jonathan. Zawieszenia percepcji. Uwaga, spektakl i kultura nowoczesna. Przetłumaczone przez Łukasz Zaremba, Iwona Kurz, red. Iwona Kurz. Warszawa: WUW, 2009.

Gloger, Maciej. „Pozytywizm: między nowoczesnością a modernizmem", Pamiętnik Literacki, z. 1 (2007).

Głowiński, Michał. Powieść młodopolska. Studium z poetyki historycznej. Kraków: Universitas, 1997.

Ilmurzyńska, Halina, Stepnowska, Agnieszka. Księgozbiór Bolesława Prusa, red. Zygmunt Szweykowski. Warszawa: Stowarzyszenie Bibliotekarzy Polskich, 1965.

Irvin, Michael. Picturing. Description and Illusion in the Nineteenth-Century Novel. London: George Allen, 1979.

Kościewicz, Katarzyna. Doświadczenie nowoczesności w "Lalce" $i$,Emancypantkach" Bolesława Prusa. W Bolesław Prus. Pisarz, publicysta, myśliciel. Zredagowane przez Maria Woźniakiewicz-Dziadosz i Stanisław Fita. Lublin: Wydawnictwo UMCS, 2003.

Markiewicz, Henryk. Młoda Polska a dziedzictwo pozytywizmu. W Dialogi z tradycja. Rozprawy i szkice historycznoliterackie. Kraków: Universitas, 2007.

Mitosek, Zofia. „Lalka” - epizod czy nazwa? W Mimesis. Zjawisko i problem. Warszawa: Wydawnictwo Naukowe PWN, 1997.

Morris, Pam. Realism. London: Routledge, 2003.

Murray, Clark. Zasady psychologii. Podręcznik. Przetłumaczone przez Henryk Wernic, Jan Władysław Dawid, wyd. II. Warszawa: Teodor Paprocki i S-ka, 1906.
Ochorowicz, Julian. $Z$ dziennika psychologa. Wrażenia, uwagi i spostrzeżenia. Warszawa: Władysław Dębski 1876.

Paczoska, Ewa. „«Lalka» - balkony i wnętrza”. "Lalka" i inne. Studia $w$ stulecie polskiej powieści realistycznej. Zredagowane przez Józef Bachórz i Michał Głowiński. Warszawa: IBL PAN, 1992.

Pavel, Thomas. „The Novel in Search of Itself: A Historical Morphology". W The Novel. Vol. 2: Forms and Themes. Zredagowane przez Franco Moretti. Princeton-Oxford: Princeton University Press, 2006.

Prus, Bolesław. Kroniki. Opracowane przez Zygmunt Szweykowski, t. 9. Warszawa: PIW 1960.

Lalka. Opracowane przez Józef Bachórz. Wyd. II, przejrzane. Wrocław: Ossolineum, 1998.

. Notatki twórcze. Tom II: Notatki o kompozycji 1886-1889. Opracowane przez Magdalena Kreft, Anna Martuszewska. Warszawa-Lublin: Towarzystwo Literackie im. Adama Mickiewicza - Episteme, 2016.

Sobieraj, Tomasz. „«Lalka» na horyzoncie dziewiętnastowieczności (modernizmu). W Świat „Lalki”. 15 studiów. Zredagowane przez Jakub A. Malik. Lublin: Towarzystwo Naukowe KUL, 2005.

Szweykowski, Zygmunt. Twórczość Bolesława Prusa, wyd. II. Warszawa: PIW, 1972.

Taine, Hipolit. O inteligencji. Przetłumaczone przez Stanisław Tomaszewski. Warszawa: Skład Główny Redakcji „Niwy”, 1873. 


\title{
SŁOWA KLUCZOWE:
}

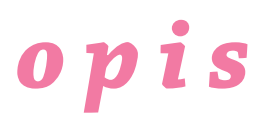

\section{PSYCHOLOGIA}

\begin{abstract}
ABstrakT:
Artykuł określa znaczenie późnodziewiętnastowiecznych badań i refleksji psychologicznych dla konstruowania opisów w Lalce Bolesława Prusa. Kwestie związane z opisem świata i człowieka - jak pokazują autorskie „notatki o kompozycji” pisarza z tego czasu - budowały ważny wątek jego epistemologicznej i artystycznej refleksji. Zapiski teoretyczne autora Lalki pozwalają ukazać tę powieść w nieco innym świetle - jako poligon wypracowanych w psychologicznej kuźni technik wpływu i podsuwania wrażeń zaciekawionemu czytelnikowi.
\end{abstract}


teorie | Marcin Jauksz, Cienie codzienności. Poetyka opisu w Lalce...

\title{
PSYCHOLOGIA POZYTYWIZMU
}

\author{
teoria kompozycji
}

\section{NOTA O AUTORZE:}

Marcin Jauksz - dr, literaturoznawca i filmoznawca, adiunkt w Zakładzie Literatury Pozytywizmu i Młodej Polski Uniwersytetu im. Adama Mickiewicza w Poznaniu. W 2010 r. obronił rozprawę doktorską Krytyka dziewiętnastowiecznego rozumu. Źródła i konteksty „Pałuby” Karola Irzykowskiego, nagrodzoną w Konkursie im. Konrada i Marty Górskich w 2011 r. i opublikowaną cztery lata później przez wydawnictwo Universitas. Interesuje się psychologizmem w prozie późnego wieku XIX i kształtującymi się wówczas zasadami kompozycji dzieła literackiego oraz filmowymi fabułami o dojrzewaniu na progu XXI stulecia. Stypendysta rządu francuskiego w latach 2008-2009 oraz programu Fulbright w latach 2018-2019; publikował między innymi w „Wieku XIX”, „Porównaniach”, „Lampie” i „Polonistyce”. 